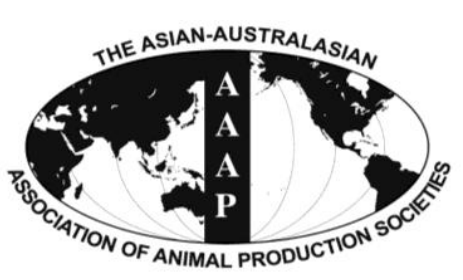

Open Access

Asian Australas. J. Anim. Sci.

Vol. 28, No. 1 : 58-68 January 2015

http://dx.doi.org/10.5713/ajas.14.0418

www.ajas.info

pISSN 1011-2367 elSSN 1976-5517

\title{
Changes of Serum Calcium Concentration, Frequency of Ruminal Contraction and Feed Intake Soon after Parturition of Dairy Cows Fed Difructose Anhydride III
}

\author{
S. Wynn, M. Teramura ${ }^{1}$, T. Sato ${ }^{1}$, and M. Hanada ${ }^{2, *}$ \\ United Graduate School of Agricultural Science, Iwate University, Morioka, Iwate 020-8550, Japan
}

\begin{abstract}
Requirements to control the large decrease in serum calcium (Ca) due to parturition and to increase the feed intake soon after parturition have been well accepted in dairy cows. This study was aimed to investigate the feed intake affected by serum Ca concentration with difructose anhydride (DFA) III supplement in dairy cows soon after parturition. Fourteen transition Holstein cows were divided into DFA and control (CONT) groups within 1 to 5 parity variations in each group. Measurement schedule for an individual cow was from $14 \mathrm{~d}$ before parturition to $7 \mathrm{~d}$ following parturition. The cows in DFA group were supplied $0.2 \mathrm{~kg} / \mathrm{head} / \mathrm{d}$ of DFA III feed containing $40 \mathrm{~g}$ of pure DFA III while the cows in CONT group received no DFA III. Other feeding procedures were the same for all cows in both groups. At parturition (d 0), serum Ca concentration sharply declined in both groups $(\mathrm{p}<0.05)$. Time interval for recovery from decreased serum Ca to its normal range $(>9.0 \mathrm{mg} / \mathrm{dL})$ tended to be faster in DFA group $(12 \mathrm{~h})$ than in the CONT group $(48 \mathrm{~h})$, but the differences were not significant. Active ruminal contraction was observed in DFA group at following parturition of $\mathrm{d} 1$ $(\mathrm{p}<0.05), \mathrm{d} 3(\mathrm{p}<0.05)$, and d $5(\mathrm{p}<0.01)$. Dry matter (DM) intake did not differ between the groups. However, positive correlations were observed between serum Ca concentration and ruminal contraction $(\mathrm{p}<0.001)$, and between ruminal contraction and DM intake $(\mathrm{p}<0.001)$ during following parturition. According to multiple regression analysis $\left(\mathrm{R}^{2}=0.824, \mathrm{p}<0.001\right)$, the DM intake was positively affected by serum $\mathrm{Ca}$ concentration and ruminal contraction. These results suggest that feed intake soon after parturition in dairy cows can be increased by improvement of serum Ca concentration and active ruminal contraction, but DFA III supplementation in this study did not improve the lower serum Ca concentration due to parturition. (Key Words: Dairy Cows, Difructose Anhydride III, Feed Intake, Serum Calcium Concentration, Ruminal Contraction)
\end{abstract}

\section{INTRODUCTION}

Physiological and metabolic changes at or soon after parturition in dairy cows have been reported by Goff and Horst (1997) and Drackley (1999). Consistent with these changes, the cow has to confront a lower $\mathrm{Ca}$ concentration in the blood and a feed intake lower than it requires. It might be impossible to avoid these changes (Goff, 2004;

\footnotetext{
* Corresponding Author: M. Hanada. Tel: +81-155-49-5482, Fax: +81-155-49-5489, E-mail: hanada@obihiro.ac.jp

${ }^{1}$ Research Center of Nippon Beet Sugar Mfg. Co., Ltd, Obihiro, Hokkaido 080-0831, Japan.

${ }^{2}$ Department of Life Science and Agriculture, Obihiro University of Agriculture and Veterinary Medicine, Obihiro, Hokkaido 0808555, Japan.

Submitted Jun. 5, 2014; Revised Aug. 1, 2014; Accepted Sept. 4, 2014
}

Grummer et al., 2004). Imbalances between lower feed intake and higher nutrient demand lead to negative energy related metabolic disorders and other infectious diseases (Herdt, 1988; Drackley et al., 2005), which can threaten the productive performances. To alleviate these problems, rapid increase of feed intake at or soon after parturition is desired. Several ways aimed to increase the feed intake in dairy cows have been suggested (Grant and Albright, 1995; Ingvartsen and Andersen, 2000; Hayirli et al., 2002), but methods remain elusive.

On the other hand, serum $\mathrm{Ca}$ decline at or soon after parturition might be an unavoidable mechanism in dairy cows, especially in aged cows (Horst et al., 1990; Goff et al., 1991) due to expeditious loss of Ca by milk synthesis, and less efficiency of $\mathrm{Ca}$ absorption by the intestinal transcellular pathway (Horst et al., 1990) and inactivation of 
bone Ca resorption pathway (Ramberg et al., 1970; Kamiya et al., 2005). Lower serum Ca concentration in the blood can induce the cow to develop the mineral related metabolic disorders involving hypocalcemia, milk fever, mastitis, retain placenta, displaced abomasum, uterine involution and delayed ovulation (Curtis et al., 1983; Borsberry and Dobson, 1989; Jonsson et al., 1999). Kimura et al. (2006) also reported that hypocalcemic cows had impaired immune cell responses and were susceptible to infectious diseases. To shut down these impediments, stopping the declined serum $\mathrm{Ca}$ by parturition is desired as fast as possible soon after parturition. Several ways aimed to prevent the decline serum Ca have been suggested in dairy cows (Jonsson and Pehrson, 1970; Goff and Horst, 1993; Horst et al., 1997), but a complete solution is still not declared.

Furthermore, serum Ca plays a unique role in muscular contractive activities (Johansson, 1987; Van Breemen and Saida, 1989). Passage rate of digesta through the gastrointestinal tract decreases with the decrease in serum Ca concentration in sheep and cow (Huber et al., 1981; Daniel, 1983) which can impact on feed intake and productive performances. Forbes (1995) reported that enhancement of reticulo-rumen motility could increase feed intake. According to these reports, improvement of feed intake soon after parturition in dairy cows might be impossible without active ruminal contraction and optimal concentration of serum $\mathrm{Ca}$. It should be therefore considered that inhibition of the large decline of serum $\mathrm{Ca}$ by parturition is a fundamental approach not only for solving the $\mathrm{Ca}$ related disorders but also for activating the ruminal contraction and improving the feed intake soon after parturition in dairy cows.

A disaccharide crystal, difructose anhydride (DFA) III containing two fructose units, can be obtained from inulin of chicory root (Kikuchi et al., 2009). It has loosening effect on the tight junction of intestinal epithelial cells, allowing the inflow of $\mathrm{Ca}$ like nutrients via paracellular pathway (Ballard et al., 1995; Mineo et al., 2002). Enhancement of Ca uptake by DFA III supplement has been identified in rats and humans (Suzuki et al., 1998; Mineo et al., 2004; Shigematsu et al., 2004). Sato et al. (2007) proved the inhibitory effect of DFA III on serum Ca decline due to parturition in multiparous cows; however they did not mention its effect on feed intake. More recently, Sato et al. (2012) proved that DFA III has a positive effect on immunoglobulin $\mathrm{G}$ absorption in newborn calves. Reports of DFA III for dairy cows are few and additional information is required to confirm its effectiveness in dairy cows.

In our study, we hypothesized two positive effects in dairy cow: i) serum $\mathrm{Ca}$ concentration decreased by parturition could be improved by DFA III supplement; ii) feed intake soon after parturition could be increased by improvement of serum $\mathrm{Ca}$ concentration. This study was aimed to investigate the feed intake affected by serum $\mathrm{Ca}$ concentration with DFA III supplement in dairy cows soon after parturition.

\section{MATERIALS AND METHODS}

Animal measurements were conducted at Field Science Centre (FSC), Obihiro University of Agriculture and Veterinary Medicine, Obihiro, Hokkaido, Japan. Cows used in this study were cared for and maintained according to the regulations for animal experiments in Obihiro University of Agriculture and Veterinary Medicine, Obihiro, Hokkaido, Japan.

\section{Animals and feeding procedures}

Fourteen transition Holstein cows kept in FSC were allotted into two groups: DFA III supplied (DFA) group $(\mathrm{n}=$ 7 ; body weight $[\mathrm{BW}]=755 \pm 29.6 \mathrm{~kg}$; body condition score $[\mathrm{BCS}]=3.3 \pm 0.07)$ and DFA III unsupplied or control $(\mathrm{CONT})$ group $(\mathrm{n}=7 ; \mathrm{BW}=757 \pm 31.0 \mathrm{~kg} ; \mathrm{BCS}=$ $3.4 \pm 0.09$ ) while cow parity varied from 1 to 5 ( 1 head in parity 1, 2, 4, and 5; 3 heads in parity 3) for each group. Measurement schedule for individual cows in each group was from $14 \mathrm{~d}$ before parturition to $7 \mathrm{~d}$ following parturition. Before parturition period, cows were assigned in a free stall barn and allowed to access the offered diets from individual door feeders equipped with an electronic gate opening system (one cow per gate per feeder). Close to parturition (approximately $\leq 24 \mathrm{~h}$ before parturition), cows were moved into the maternal hospital pen and kept in individual stalls and, the diets were offered separately. Newborn calves were weighed and separated from their mothers within $1 \mathrm{~h}$ following parturition and kept in individual calf pens. Their dams were kept in the hospital pen until the end of measurement period.

The DFA III feed used as supplement in our study was manufactured by Nippon Beet Sugar Mfg. Co., Ltd (Obihiro, Japan) and it was composed of $80 \%$ beet pulp and $20 \%$ pure DFA III. Before feeding the other basal diets, the cows in DFA group were supplied $0.2 \mathrm{~kg} / \mathrm{head} / \mathrm{d}$ of DFA III feed (containing $40 \mathrm{~g}$ of pure DFA III) while the cows in CONT group were not supplied with any DFA III. Other offered diets and feeding procedures were same to all cows in both groups. Diets were offered twice a day (06:00 h and 17:30 h) throughout the measurement period. Ingredient and chemical compositions of the offered diets in this study are shown in Table 1.

Before parturition period (from before parturition $14 \mathrm{~d}$ to parturition time), $30.0 \mathrm{~kg} / \mathrm{head} / \mathrm{d}$ of total mixed ration (TMR, formulated to be forage and concentrate ratio [F:C] of $89: 11$ ) and $6.0 \mathrm{~kg} / \mathrm{head} / \mathrm{d}$ of grass hay were offered by restricted feeding. Following parturition period (from 
Table 1. Ingredient and chemical compositions of DFA III feed and other basal diets

\begin{tabular}{|c|c|c|c|c|c|}
\hline & \multirow{2}{*}{ DFA III feed ${ }^{1}$} & \multicolumn{2}{|c|}{ Before parturition } & \multicolumn{2}{|c|}{ Following parturition } \\
\hline & & $\mathrm{H}$ & $\mathrm{TMR}^{2}$ & Top-dressed $^{3}$ & TMR \\
\hline Ingredient compositions $^{4}$ & ----------------. & - & of fresh & ------------------- & - \\
\hline Grass hay & - & 100.00 & - & - & - \\
\hline Grass silage & - & - & 30.83 & - & 42.91 \\
\hline Corn silage & - & - & 57.80 & - & 33.44 \\
\hline Steamed flaked corn & - & - & - & - & 10.69 \\
\hline Concentrate $\mathrm{C}_{17}$ & - & - & 7.71 & - & - \\
\hline Concentrate $\mathrm{C}_{18}$ & - & - & - & 95.24 & 7.01 \\
\hline Soybean meal & - & - & 2.89 & - & 3.62 \\
\hline Beet pulp & 80.00 & - & - & - & 1.96 \\
\hline Magnesium oxide & - & - & - & - & 0.04 \\
\hline Calcium phosphate & - & - & - & 4.76 & 0.10 \\
\hline Calcium carbonate & - & - & - & - & 0.20 \\
\hline Vitamin (premixed) & - & - & 0.77 & - & 0.03 \\
\hline DFA III & 20.00 & - & - & - & - \\
\hline \multicolumn{6}{|l|}{ Chemical compositions ${ }^{5}$} \\
\hline DM & 90.41 & 86.92 & 54.21 & 86.44 & 38.54 \\
\hline $\mathrm{CP}$ & 7.50 & 12.85 & 13.42 & 22.90 & 15.81 \\
\hline ADICP & 0.50 & 2.10 & 1.40 & 1.22 & 1.12 \\
\hline NDICP & 2.69 & 7.10 & 3.65 & 3.42 & 2.62 \\
\hline $\mathrm{ADF}$ & 12.50 & 40.12 & 30.52 & 11.2 & 25.20 \\
\hline $\mathrm{NDF}$ & 23.32 & 63.50 & 49.81 & 22.85 & 42.21 \\
\hline NFC & 65.53 & 18.87 & 28.9 & 46.65 & 32.88 \\
\hline $\mathrm{EE}$ & 0.80 & 2.30 & 2.89 & 3.72 & 3.83 \\
\hline Ash & 4.20 & 9.20 & 8.01 & 6.34 & 7.21 \\
\hline Lignin & 3.41 & 6.56 & 4.42 & 2.81 & 3.21 \\
\hline $\mathrm{Ca}$ & 0.38 & 0.45 & 0.40 & 1.10 & 0.71 \\
\hline $\mathrm{P}$ & 0.05 & 0.25 & 0.21 & 0.60 & 0.43 \\
\hline $\mathrm{Mg}$ & 0.11 & 0.20 & 0.21 & 0.30 & 0.30 \\
\hline $\mathrm{K}$ & 0.54 & 1.86 & 2.01 & 0.92 & 1.71 \\
\hline NEL & 1.57 & 1.27 & 1.44 & 1.78 & 1.58 \\
\hline
\end{tabular}

DFA, difructose anhydride; H, grass hay; TMR, total mixed ration; DM, dry matter; CP, crude protein; ADICP, acid detergent insoluble crude protein; NDICP, neutral detergent insoluble crude protein; ADF, acid detergent fiber; NDF, neutral detergent fiber; NFC, non-fibrous carbohydrate; EE, ether extract; Ca, calcium; P, phosphorus; Mg, magnesium; K, potassium; NEL, net energy for lactation; -, no ingredient.

${ }^{1}$ DFA III feed (Miracle oligosaccharide, Nippon Beet Sugar Mfg. Co., Ltd, Japan) supplemented to cows in DFA group.

${ }^{2}$ TMR offered to cows in DFA and CONT groups.

${ }^{3}$ Values in chemical composition of the top-dressed are only by concentrate $\mathrm{C}_{18}$.

${ }^{4}$ Commercial products: concentrate $\mathrm{C}_{17}$ (Dry-base 17, Hokuren Cooperative Feed Mills Co., Ltd, Japan); concentrate $\mathrm{C}_{18}$ (Mo-dairy 18, Nippon Formula Feed Mfg. Co., Ltd, Japan); soybean meal (Daizu meal, J-Oil Mills, INC, Japan); beet pulp (Beet pulp pellet, Nippon Beet Sugar Mfg. Co., Ltd, Japan); magnesium oxide (Magumaito, Yushiseihin Co., Ltd, Japan); calcium phosphate (Dibasic, Obanaya Cementex Co., Ltd, Japan); calcium carbonate (Nittetsukou Tancal, Nittetsu Mining Co., Ltd, Japan); premixed vitamins (Yoka vita-M-mash, Snow Brand Seed Co., Ltd, Japan).

${ }^{5}$ Values are average of weekly analysis.

parturition time to $7 \mathrm{~d}$ following parturition), TMR formulated to be $\mathrm{F}: \mathrm{C}$ of $76: 24$ was offered by ad-libitum feeding. In addition, $2.0 \mathrm{~kg} / \mathrm{head} / \mathrm{d}$ of concentrate $\mathrm{C}_{18}$ (Modairy 18, Nippon Formula Feed Mfg. Co., Ltd, Kanagawa, Japan) and $0.1 \mathrm{~kg} / \mathrm{head} / \mathrm{d}$ calcium phosphate (Dibasic, Obanaya Cementex Co., Ltd, Aichi, Japan) were supplied as top-dressed on TMR following the parturition period.
Drinking water and mineral block (KNZ salt licks, Akzo Nobel N.V, Hengelo, The Netherlands) were always available for all cows in both groups throughout the measurement period.

\section{Sampling and measurement procedures}

Offered diet samples were collected once a week. 
Residues from individual cows were weighed and $1 \%$ of residue was sampled daily. The DM, crude protein, ether extract and ash contents in the offered diets and in the residues were determined by methods described in AOAC (2003). Neutral detergent fiber, acid detergent fiber, and lignin were analyzed according to methods of Van Soest et al. (1991). Neutral detergent insoluble crude protein and acid detergent insoluble crude protein were analyzed according to the procedures of Coblentz et al. (2010). Non fibrous carbohydrate and net energy for lactation were calculated using NRC (2001) equations. Dietary calcium $(\mathrm{Ca})$, phosphorus $(\mathrm{P})$, magnesium $(\mathrm{Mg})$ and potassium $(\mathrm{K})$ were analyzed by inductively coupled plasma emission spectroscopy analysis method (ICPE-9000, Shimadzu Corporation, Tokyo, Japan). Individual feed intake was calculated on daily basis.

Blood samples were withdrawn from the caudal vein of the cow into the sampling tube (VENOJECT II, Terumo Corporation, Tokyo, Japan) at d 14, 7, 5, 3, and 1 before parturition as well as at $\mathrm{d} 0,0.25,0.5,1,2,3,4,5$, and 7 following parturition, respectively. Sampling for before parturition (d 14, 7, 5, 3, and 1) and after parturition (d 4, 5, and 7) were almost completed at 05:30 h before morning feeding, but sampling for $\mathrm{d} 0,0.25,0.5,1,2$, and 3 following parturition was performed counting from the parturition hour. Within $1 \mathrm{~h}$ after withdrawing, blood sample was centrifuged at 3,500 rpm for $10 \mathrm{~min}$ at room temperature (Hitachi Centrifuge 05P-21, Hitachi Koki Co., Ltd, Tokyo, Japan). Obtained serum was kept at $-30^{\circ} \mathrm{C}$ (Biomedical Freezer, Sanyo Electric Co., Ltd, Osaka, Japan) until analysis. Serum $\mathrm{Ca}$ concentration was determined using Automatic Clinical Chemistry Analyzer (TBA-120FR, Toshiba Medical Systems Corporation, Tochigi, Japan).

Ruminal contraction was auscultated from upper left flank of the cow using stethoscope connected sound recorder (ICR-S340RM, Sanyo Electric Co., Ltd, Osaka, Japan). Recording was performed for $5 \mathrm{~min}$ in each auscultation at $\mathrm{d} 14$, and 7 before parturition and at $\mathrm{d} 0$, $0.25,0.5,1,2,3,4,5$, and 7 following parturition. Recording before parturition (d 14 and 7) and after parturition ( $\mathrm{d} 4,5$, and 7$)$ were almost completed at 05:30 h before morning feeding (soon after blood sampling), but sampling for $\mathrm{d} 0,0.25,0.5,1,2$, and 3 following parturition was performed counting from parturition hour. The number of ruminal contraction (time/min) was determined by dividing the number of contract frequencies within $5 \mathrm{~min}$ recording by 5 from both of direct auscultation and checking the sound waves processed by Sound it! 5.0 for windows (SIT50W, Internet Co., Ltd, Osaka, Japan) (Figure 1).

The BW was measured twice a week. The values were an average of twice a week measurements. Before parturition, the cows were weighed before morning feeding. After parturition, the cows were weighed at a period between after morning milking and before morning feeding. Milking was performed twice a day by bucket milker in the hospital pen. Milk samples were collected from each milking and, the components (fat, lactose, protein) were analyzed by Automatic Milk Analyzer (Milko-Scan FT+, FOSS, Hillerød, Denmark), and the values were an average of each analysis.

\section{Data analysis}

Data were expressed as mean \pm standard error of the mean (SEM) for the measurements of cows in each group. Statistical differences between the mean of groups were assessed using t-test. Comparisons of time-point measurements within a group were examined by least significant difference of one-way analysis of variance. Chisquare test was used to compare the time interval for recovery from the decline in serum $\mathrm{Ca}$ concentration soon after parturition between the groups. Multiple regression analysis was performed using four variable factors of first 7 $\mathrm{d}$ following parturition (the average of serum $\mathrm{Ca}$ concentration, ruminal contraction, milk yield, and daily BW change) to predict their effects on DM intake during first $7 \mathrm{~d}$ following parturition. The standard partial regression coefficient $(\beta)$ was determined for each variable factor to compare its effects on DM intake. Correlations between the parameters were determined by Pearson's procedure. All the analyses were run by Statistical Package for the Social Sciences (SPSS) for windows, version 16.0 (SPSS Inc., Chicago, IL, US), and statistical differences were declared at $\mathrm{p}<0.05, \mathrm{p}<0.01$, and $\mathrm{p}<0.001$, respectively.

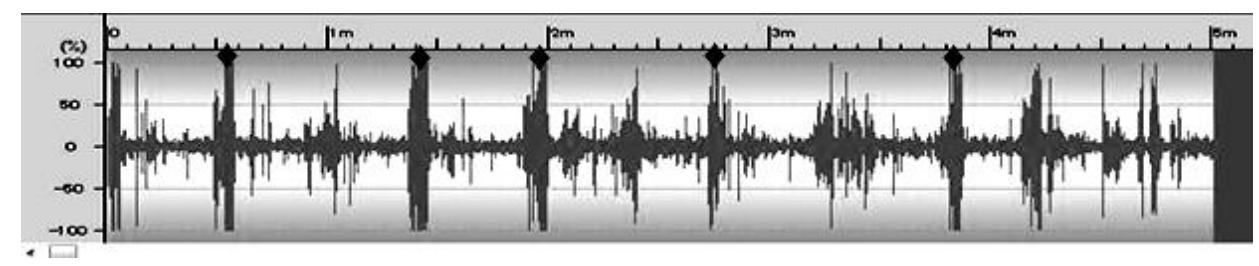

Figure 1. Sound waves of ruminal contractions processed by Sound it! 5.0 for windows (SIT50W, Internet Co., Ltd, Japan). Recording was performed for $5 \mathrm{~min}$ from upper left flank of the cow using stethoscope connected sound recorder (ICR-S340RM, Sanyo Electric Co., Ltd, Japan). Closed symbols ( $\downarrow$ ) indicate the time regions/ places in which ruminal contractions occurred. 
Table 2. Changes in serum calcium concentration before and following parturition periods relative to cows in DFA and CONT groups $^{1}$

\begin{tabular}{lccc}
\hline Day & DFA group & CONT group & p-value \\
\hline Before parturition & & & \\
14 & $9.8 \pm 0.1^{\mathrm{a}}$ & $9.9 \pm 0.2^{\mathrm{a}}$ & 0.478 \\
7 & $9.7 \pm 0.1^{\mathrm{a}}$ & $9.8 \pm 0.1^{\mathrm{a}}$ & 0.519 \\
5 & $9.8 \pm 0.1^{\mathrm{a}}$ & $9.6 \pm 0.1^{\mathrm{a}}$ & 0.252 \\
3 & $9.6 \pm 0.1^{\mathrm{a}}$ & $9.8 \pm 0.1^{\mathrm{a}}$ & 0.217 \\
1 & $9.3 \pm 0.4^{\mathrm{a}}$ & $9.9 \pm 0.3^{\mathrm{a}}$ & 0.258 \\
Following parturition & & \\
0 & $8.1 \pm 0.4^{\mathrm{b}}$ & $7.9 \pm 0.5^{\mathrm{b}}$ & 0.827 \\
0.25 & $8.0 \pm 0.4^{\mathrm{b}}$ & $7.8 \pm 0.6^{\mathrm{b}}$ & 0.742 \\
0.5 & $9.6 \pm 0.5^{\mathrm{a}}$ & $8.9 \pm 0.5^{\mathrm{ab}}$ & 0.375 \\
1 & $9.3 \pm 0.4^{\mathrm{a}}$ & $8.9 \pm 0.9^{\mathrm{ab}}$ & 0.515 \\
2 & $9.9 \pm 0.3^{\mathrm{a}}$ & $9.4 \pm 0.3^{\mathrm{a}}$ & 0.200 \\
3 & $10.0 \pm 0.3^{\mathrm{a}}$ & $9.7 \pm 0.3^{\mathrm{a}}$ & 0.555 \\
4 & $10.0 \pm 0.2^{\mathrm{a}}$ & $9.5 \pm 0.3^{\mathrm{a}}$ & 0.150 \\
5 & $9.6 \pm 0.2^{\mathrm{a}}$ & $10.1 \pm 0.3^{\mathrm{a}}$ & 0.163 \\
7 & $9.5 \pm 0.1^{\mathrm{a}}$ & $9.8 \pm 0.2^{\mathrm{a}}$ & 0.177 \\
\hline
\end{tabular}

DFA, difructose anhydride.

${ }^{1}$ DFA group, cows group that received DFA III supplement; CONT group, cows group that did not receive any DFA III.

Values are expressed as mean \pm standard error of the mean.

${ }^{\mathrm{a}, \mathrm{b}}$ Different superscripts within a group are statistically different at $\mathrm{p}<0.05$.

\section{RESULTS}

\section{Serum calcium concentration}

The results of serum $\mathrm{Ca}$ concentration are shown in Table 2. Before parturition period, serum Ca concentrations were above $9.0 \mathrm{mg} / \mathrm{dL}$ in both groups, and they did not differ between the groups ( $p>0.05)$. At parturition (d 0), serum Ca concentrations dropped sharply $(\mathrm{p}<0.05)$ in both groups $(8.1 \pm 0.4 \mathrm{mg} / \mathrm{dL}$ in DFA group and $7.9 \pm 0.5 \mathrm{mg} / \mathrm{dL}$ in CONT group) and the lowest serum Ca concentrations were observed at $\mathrm{d} 0.25$ following parturition $(8.0 \pm 0.4 \mathrm{mg} / \mathrm{dL}$ in DFA group and $7.8 \pm 0.6 \mathrm{mg} / \mathrm{dL}$ in CONT group). Thereafter the cows in both groups began to regain their serum $\mathrm{Ca}$ concentrations to normal ranges (above $9.0 \mathrm{mg} / \mathrm{dL}$, NRC, 2001). With numerically higher concentration, the cows in DFA group almost restored the serum $\mathrm{Ca}$ to the normal range $12 \mathrm{~h}$ after parturition, but the cows in CONT group took $48 \mathrm{~h}$ to restore the normal range of serum Ca. Statistical differences in serum $\mathrm{Ca}$ concentration and time interval for recovery of serum $\mathrm{Ca}$ levels following parturition to their normal range were not significant between the groups ( $p>0.05)$.

\section{Ruminal contracted frequency}

The results of ruminal contraction are shown in Figure 2. Average ruminal contraction during $14 \mathrm{~d}$ before parturition in DFA group was $1.5 \pm 0.1 \mathrm{time} / \mathrm{min}$, and that in CONT group was $1.4 \pm 0.1 \mathrm{time} / \mathrm{min}$, and they did not differ

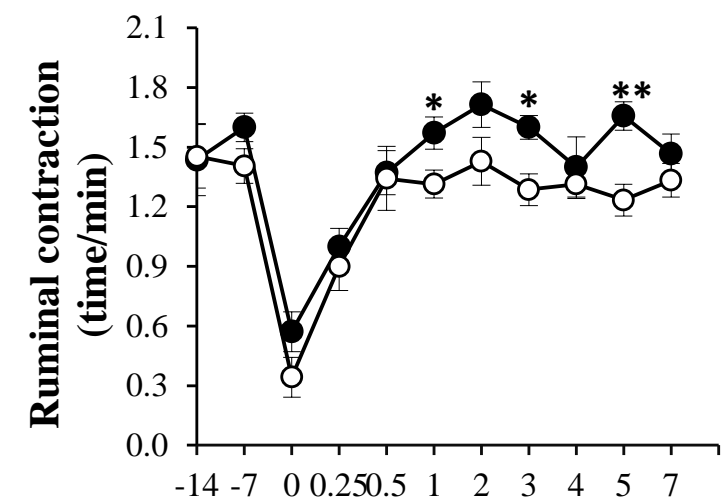

Relative to parturition (d)

Figure 2. Ruminal contractions (time/min) during, before and following parturition. Symbols: $(-\bullet-)$ represents to the cows in difructose anhydride (DFA) group that received DFA III supplement, and (-O-) represents to the cows in CONT group that did not receive DFA III. The vertical bars on time-point measurements indicate the standard errors of the mean. $*$ and $* *$ indicate statistically differences between the groups at $\mathrm{p}<0.05$ and $\mathrm{p}<0.01$, respectively.

between the groups ( $p>0.05)$. At parturition (d 0), ruminal contraction sharply decreased $(\mathrm{p}<0.05)$ in both groups $(0.6 \pm 0.1 \mathrm{time} / \mathrm{min}$ in DFA group and $0.3 \pm 0.1 \mathrm{time} / \mathrm{min}$ in CONT group), and then began to recovery gradually. Following parturition, active ruminal contraction was observed in DFA group at $\mathrm{d} 1(\mathrm{p}<0.05), \mathrm{d} 3(\mathrm{p}<0.05)$, and $\mathrm{d}$ $5(\mathrm{p}<0.01)$, respectively.

\section{Feed intake}

The results of feed intake are shown in Table 3. Average DM intake values during $14 \mathrm{~d}$ before parturition were $12.1 \pm 0.8 \mathrm{~kg} / \mathrm{d}(1.6 \% \mathrm{BW})$ in DFA group and $12.0 \pm 0.9 \mathrm{~kg} / \mathrm{d}$ $(1.6 \% \mathrm{BW})$ in CONT group, and they did not differ between the groups ( $p>0.05)$. The lowest DM intake was observed at $\mathrm{d} 1$ before parturition, and then DM intake began to increase gradually following parturition in both groups. During first $7 \mathrm{~d}$ following parturition, DM intake of DFA group increased from $14.8 \pm 2.8 \mathrm{~kg} / \mathrm{d}(2.0 \% \mathrm{BW})$ to $19.6 \pm 2.1 \mathrm{~kg} / \mathrm{d}(2.9 \% \mathrm{BW})$, and that of CONT group increased from $14.2 \pm 1.2 \mathrm{~kg} / \mathrm{d}(1.9 \% \mathrm{BW})$ to $19.2 \pm 2.2 \mathrm{~kg} / \mathrm{d}$ $(2.7 \% \mathrm{BW})$, respectively. DM intake during first $7 \mathrm{~d}$ following parturition tended to be numerically higher in DFA group than CONT group, but significant differences were not observed between the groups ( $\mathrm{p}>0.05$ ).

Through the measurement period, Ca intakes were not different between the groups $(\mathrm{p}>0.05)$. Average Ca intakes, during $14 \mathrm{~d}$ before parturition were $42.1 \pm 2.8 \mathrm{~g} / \mathrm{d}$ (DFA group) and $42.4 \pm 4.2 \mathrm{~g} / \mathrm{d}$ (CONT group), and during first $7 \mathrm{~d}$ following parturition were $101.4 \pm 15.1 \mathrm{~g} / \mathrm{d}$ (DFA group) and $94.6 \pm 14.3 \mathrm{~g} / \mathrm{d}$ (CONT group), respectively. 
Table 3. Changes in dry matter and calcium intakes before and following parturition periods relative to cows in DFA and CONT groups ${ }^{1}$

\begin{tabular}{|c|c|c|c|c|c|c|}
\hline \multirow{2}{*}{ Day } & \multicolumn{3}{|c|}{ DM intake $(\mathrm{kg} / \mathrm{d}, \% \mathrm{BW})$} & \multicolumn{3}{|c|}{ Ca intake $(\mathrm{g} / \mathrm{d})$} \\
\hline & DFA group $^{1}$ & CONT group $^{1}$ & p-value & DFA group & CONT group & p-value \\
\hline \multicolumn{7}{|c|}{ Before parturition } \\
\hline 14 & $12.2 \pm 0.8^{\mathrm{a}}(1.6)$ & $12.1 \pm 1.0^{\mathrm{a}}(1.6)$ & 0.945 & $39.8 \pm 3.0^{\mathrm{a}}$ & $41.8 \pm 4.3^{\mathrm{a}}$ & 0.713 \\
\hline 7 & $12.8 \pm 0.8^{\mathrm{a}}(1.6)$ & $12.2 \pm 0.7^{\mathrm{a}}(1.6)$ & 0.596 & $45.8 \pm 3.4^{\mathrm{a}}$ & $44.3 \pm 4.0^{\mathrm{a}}$ & 0.786 \\
\hline 5 & $12.5 \pm 0.8^{\mathrm{a}}(1.6)$ & $12.8 \pm 1.0^{\mathrm{a}}(1.6)$ & 0.804 & $44.2 \pm 2.5^{\mathrm{a}}$ & $48.2 \pm 4.3^{\mathrm{a}}$ & 0.885 \\
\hline 3 & $12.6 \pm 0.6^{\mathrm{a}}(1.6)$ & $12.0 \pm 0.7^{\mathrm{a}}(1.6)$ & 0.573 & $45.7 \pm 2.3^{\mathrm{a}}$ & $44.5 \pm 5.3^{\mathrm{a}}$ & 0.808 \\
\hline 1 & $11.8 \pm 1.0^{\mathrm{a}}(1.6)$ & $10.9 \pm 1.1^{\mathrm{a}}(1.5)$ & 0.531 & $44.0 \pm 4.3^{\mathrm{a}}$ & $39.2 \pm 1.9^{\mathrm{a}}$ & 0.170 \\
\hline \multicolumn{7}{|c|}{ Following parturition } \\
\hline 0 & $14.8 \pm 2.8^{\mathrm{ab}}(2.0)$ & $14.2 \pm 1.2^{\mathrm{ab}}(1.9)$ & 0.848 & $91.8 \pm 17.3^{\mathrm{b}}$ & $73.7 \pm 12.4^{\mathrm{ab}}$ & 0.413 \\
\hline 1 & $17.2 \pm 1.3^{\mathrm{bc}}(2.4)$ & $15.5 \pm 1.8^{\mathrm{abc}}(2.0)$ & 0.466 & $104.5 \pm 13.7^{\mathrm{b}}$ & $86.8 \pm 13.9^{\mathrm{bc}}$ & 0.383 \\
\hline 2 & $17.3 \pm 1.0^{\mathrm{bc}}(2.5)$ & $16.6 \pm 1.9^{\mathrm{bc}}(2.2)$ & 0.743 & $97.3 \pm 13.4^{\mathrm{b}}$ & $99.8 \pm 11.6^{\mathrm{bc}}$ & 0.890 \\
\hline 3 & $17.9 \pm 1.0^{\mathrm{bc}}(2.6)$ & $16.9 \pm 1.5^{\mathrm{bc}}(2.3)$ & 0.565 & $97.6 \pm 16.1^{\mathrm{b}}$ & $102.2 \pm 11.4^{\mathrm{bc}}$ & 0.817 \\
\hline 4 & $17.8 \pm 1.6^{\mathrm{bc}}(2.6)$ & $16.3 \pm 1.0^{\mathrm{abc}}(2.2)$ & 0.433 & $109.3 \pm 12.1^{\mathrm{b}}$ & $97.5 \pm 07.9^{\mathrm{bc}}$ & 0.431 \\
\hline 5 & $17.7 \pm 1.2^{\mathrm{bc}}(2.6)$ & $16.3 \pm 1.7^{\mathrm{abc}}(2.3)$ & 0.508 & $105.3 \pm 11.8^{\mathrm{b}}$ & $99.0 \pm 14.2^{\mathrm{bc}}$ & 0.737 \\
\hline 6 & $18.2 \pm 2.5^{\text {bc }}(2.7)$ & $16.0 \pm 2.2^{\mathrm{bc}}(2.2)$ & 0.524 & $99.5 \pm 16.7^{b}$ & $88.9 \pm 21.8^{\mathrm{bc}}$ & 0.704 \\
\hline 7 & $19.6 \pm 2.1^{\mathrm{c}}(2.9)$ & $19.2 \pm 2.2^{c}(2.7)$ & 0.891 & $105.6 \pm 20.0^{\mathrm{b}}$ & $108.7 \pm 21.8^{\mathrm{bc}}$ & 0.919 \\
\hline
\end{tabular}

DFA, difructose anhydride; DM, dry matter; BW, body weight.

${ }^{1}$ DFA group, cows group that received DFA III supplement; CONT group, cows group that did not receive any DFA III.

Values are expressed as mean \pm standard error of the mean.

${ }_{a, b, c}$ Different superscripts within a group are statistically different at $\mathrm{p}<0.05$.

\section{Milk yield and body weight}

The results of daily milk yield and weekly body weight are shown in Table 4. Numerically higher milk yield was observed in DFA group, but significant differences were not observed in milk yield and milk composition between the groups $(\mathrm{p}>0.05)$. Average milk fat, protein and lactose contents in DFA and CONT groups during first $7 \mathrm{~d}$ following parturition were $5.4 \%$ and $6.1 \%, 4.9 \%$ and $5.6 \%$, and $4.0 \%$ and $4.1 \%$, respectively.

The BW changes were not different between the groups ( $>0.05)$ throughout the measurement period. BW of cows in both groups declined at parturition and it continued following parturition. Daily BW changes in DFA and CONT groups during first $7 \mathrm{~d}$ following parturition were $-4.6 \pm 0.5 \mathrm{~kg} / \mathrm{d}$ and $-3.8 \pm 0.7 \mathrm{~kg} / \mathrm{d}$, respectively.

\section{DISCUSSION}

Tight junction located on the luminal side of adjacent epithelial cells of the intestine is the gatekeeper of paracellular absorption pathway allowing the passage of nutrients including Ca (Ballard et al., 1995). An opening

Table 4. Daily milk yield during first $7 \mathrm{~d}$ following parturition and weekly body weight changes before and following parturition periods relative to cows in DFA and CONT groups ${ }^{1}$

\begin{tabular}{|c|c|c|c|c|c|c|}
\hline \multirow{2}{*}{ Day } & \multicolumn{3}{|c|}{ Milk yield (kg/d) } & \multicolumn{3}{|c|}{ Body weight (kg) } \\
\hline & DFA group $^{1}$ & CONT group $^{1}$ & p-value & DFA group & CONT group & p-value \\
\hline \multicolumn{7}{|c|}{ Before parturition } \\
\hline 14 & - & - & - & $757 \pm 28.5^{\mathrm{ab}}$ & $760 \pm 28.9^{\mathrm{ab}}$ & 0.946 \\
\hline 7 & - & - & - & $770 \pm 28.8^{\mathrm{a}}$ & $768 \pm 29.9^{\mathrm{a}}$ & 0.960 \\
\hline \multicolumn{7}{|c|}{ Following parturition } \\
\hline 0 & $18.7 \pm 4.3^{\mathrm{a}}$ & $16.4 \pm 4.0^{\mathrm{a}}$ & 0.709 & $708 \pm 30.4^{\mathrm{ab}}$ & $700 \pm 30.4^{\mathrm{ab}}$ & 0.871 \\
\hline 1 & $27.8 \pm 3.3^{\mathrm{b}}$ & $25.3 \pm 3.0^{\mathrm{b}}$ & 0.588 & - & - & - \\
\hline 2 & $33.2 \pm 2.6^{\mathrm{bc}}$ & $31.1 \pm 2.8^{\mathrm{bc}}$ & 0.586 & - & - & - \\
\hline 3 & $36.1 \pm 2.5^{\mathrm{c}}$ & $32.2 \pm 3.2^{\mathrm{bc}}$ & 0.366 & - & - & - \\
\hline 4 & $36.2 \pm 3.2^{\mathrm{c}}$ & $32.9 \pm 2.5^{\mathrm{bc}}$ & 0.418 & - & - & - \\
\hline 5 & $39.6 \pm 2.2^{c}$ & $36.2 \pm 2.9^{c}$ & 0.360 & - & - & - \\
\hline 6 & $39.1 \pm 2.3^{\mathrm{c}}$ & $37.9 \pm 3.2^{\mathrm{c}}$ & 0.773 & - & - & - \\
\hline 7 & $41.6 \pm 1.7^{\mathrm{c}}$ & $39.7 \pm 2.7^{\mathrm{c}}$ & 0.779 & $676 \pm 30.6^{\mathrm{b}}$ & $674 \pm 30.6^{\mathrm{b}}$ & 0.973 \\
\hline
\end{tabular}

DFA, difructose anhydride; -, no measured.

${ }^{1}$ DFA group, cows group that received DFA III supplement; CONT group, cows group that did not receive any DFA III.

Values are expressed as mean \pm standard error of the mean.

${ }_{a, b, c}$ Different superscripts within a group are statistically different at $\mathrm{p}<0.05$. 
effect of DFA III on the tight junction channel has been identified by Mineo et al. (2002). Increased Ca uptake by DFA III supplement via paracellular pathway was demonstrated in rats (Suzuki et al., 1998; Mineo et al., 2004), and humans (Shigematsu et al., 2004). Sato et al. (2007) confirmed the positive effect of DFA III on serum $\mathrm{Ca}$ concentration at parturition and its inhibitory effect on hypocalcemia in dairy cows. However, significant effects of DFA III were not observed in our study.

With numerically higher concentration, the cows in DFA group of our study almost restored the decline in serum $\mathrm{Ca}$ due to parturition to their normal ranges (above $9.0 \mathrm{mg} / \mathrm{dL}$, recommended level by NRC, 2001) at $12 \mathrm{~h}$ after parturition, but the cows in CONT group took $48 \mathrm{~h}$ to restore to the normal range (Table 2). Tendency for a shorter time interval for recovery of the decrease in Ca in DFA group might be due to the effect of DFA III supplement, but statistical differences were not observed between the groups $(p>0.05)$. These results indicate that DFA III has limited effect and it cannot always improve serum $\mathrm{Ca}$ concentration in dairy cows. This ambiguous effect of DFA III in our study might be due to large variations in serum $\mathrm{Ca}$ concentration at different number of parities within the groups. It has been also reported that low parity cows have good efficiency in $\mathrm{Ca}$ absorption themselves due to active mechanisms of $\mathrm{Ca}$ homeostasis including both of transcellular and paracellular pathways and bone resorption pathway (Goff et al., 1991; Bronner, 1992; Kamiya et al., 2005), and they can maintain the serum $\mathrm{Ca}$ at a steady concentration without any treatments. On the other hand, multiparous or high parity cows have poor efficiency in $\mathrm{Ca}$ absorption due to inactivation of transcellular pathway (Horst et al., 1990; Goff et al., 1991) and interference of bone resorption pathway (Ramberg et al., 1970; Kamiya et al., 2005) due to aging. Therefore, they are dependent on the paracellular absorption pathway to maintain the serum $\mathrm{Ca}$ at a steady concentration. Romo et al. (1991) and Kume et al. (2003) also reported that high parity in cows had a negative effect on serum $\mathrm{Ca}$ concentration, and serum $\mathrm{Ca}$ decline due to parturition in dairy cows increased with the parity. It should be considered from these reports that the action of DFA III on Ca uptake via paracellular pathway will have a relatively greater effect in multiparous cows when compared to primiparous cows. All the cows used in the study of Sato et al. (2007) were multiparous cows (parity $\geq 2$ ), and there was a significant effect of DFA III on serum Ca concentration. Sato et al. (2007) also showed that a significant effect of DFA III on serum Ca concentration at parturition was more evident in cows with parity $\geq 3$, and there was no significant effect in cows with parity 2 in their study, and it was suggested that effect of DFA III was different on different parity cows. The cows used in our study were not only multiparous but also primiparous cows in each group (1 to 5 parity variation in each group), and a clear effect of DFA III could not be detected due to the large variations in serum Ca concentration by different parity of cows within the groups. Therefore, cow parity should be considered as a factor in identifying the affect of DFA III on serum Ca concentration, and large variations in serum $\mathrm{Ca}$ concentration by different parity of cows within the groups in our study is one of the possible reasons of an unclear effect of DFA III.

Moreover, $50 \mathrm{~g}$ of DFA III (97\% purity) were supplied to the cows in the study of Sato et al. (2007) from $21 \mathrm{~d}$ before parturition to parturition, and thereafter $180 \mathrm{~g}$ of that DFA III were supplied within $0.25 \mathrm{~d}$ after parturition. In our study, $40 \mathrm{~g}$ of DFA III were supplied from $14 \mathrm{~d}$ before parturition to $7 \mathrm{~d}$ following parturition in a uniform feeding procedure. It is not clear that the failure to detect a significant difference in serum $\mathrm{Ca}$ concentration in our study might be due to different feeding procedures and feeding different amounts of DFA III. There is no additional research work in transition dairy cows to predict whether different feeding procedures and different amounts of DFA III has any different effects on serum Ca concentration at or soon after parturition. However, it should be considered as one of the possible reasons for the ambiguous effect of DFA III in our study. In addition, it might be impossible to neglect the influence of nutrient composition of the offered diets on the Ca homeostasis mechanism; especially Ca like mineral contents should be considered as an influencing factor. The decline of serum $\mathrm{Ca}$ concentration at parturition is affected by the level of $\mathrm{Ca}$ content in the offered diets before parturition. According to the recommendation of NRC (2001), the optimal range of dietary Ca content before parturition is $0.44 \%$ to $0.48 \%$. Ca content of basal diet (hay) used for before parturition period in the study of Sato et al. (2007) was $0.21 \%$ to $0.30 \%$, and that in our study was $0.45 \% \mathrm{Ca}$ in hay and $0.40 \% \mathrm{Ca}$ in TMR (Table 1). The cows in DFA and CONT groups of our study received the optimal level of dietary Ca content before parturition when compared to the study of Sato et al. (2007). In the study of Sato et al. (2007), the decreased serum Ca concentration at d 0 in the cows supplied DFA III was $8.0 \pm 0.2 \mathrm{mg} / \mathrm{dL}$, and that in the cows without DFA III was $6.6 \pm 0.3 \mathrm{mg} / \mathrm{dL}$, then significant differences occurred between the groups $(\mathrm{p}<0.01)$, but in our study, the declined serum $\mathrm{Ca}$ at $\mathrm{d} 0$ in DFA group was $8.1 \pm 0.4 \mathrm{mg} / \mathrm{dL}$ and that in CONT group was $7.9 \pm 0.5 \mathrm{mg} / \mathrm{dL}$, and significant differences were not observed between the groups ( $p>0.05$ ), due to higher serum Ca value of CONT group in our study. This higher serum Ca value of CONT group might be due to receiving of the optimal level of dietary Ca content before parturition when compared to the study of Sato et al. (2007). No further decline in serum $\mathrm{Ca}$ at $\mathrm{d} 0$ of CONT group might result in the ambiguous effect of DFA III on serum Ca concentration 
following parturition in our study. Anyway, further studies should be carried out to identify which factors are restricting improvement of serum $\mathrm{Ca}$ concentration soon after parturition by DFA III supplement.

Furthermore, it has been reported that serum $\mathrm{Ca}$ has unique role in muscular contractive activity (Johansson, 1987; Van Breemen and Saida, 1989). Huber et al. (1981) reported that rumen contraction of sheep gradually decreased according to a decreased in serum $\mathrm{Ca}$ concentration. Daniel (1983) also reported for sheep and cow that there were positive correlations between serum $\mathrm{Ca}$ concentration and contraction rate of the rumen in the ranges of serum Ca 4.0 to $12.0 \mathrm{mg} / \mathrm{dL}$. In our study, ruminal contraction sharply declined at parturition $(\mathrm{p}<0.05)$ and, then began to recover gradually following parturition which was similar to changes of serum Ca. Active frequency of ruminal contraction was observed in the cows supplied DFA III at following parturition of $\mathrm{d} 1,3$, and 5 (Figure 2), though there were no significant differences in serum $\mathrm{Ca}$ concentration between the groups. The reason for this is still unclear. However, a positive correlation was observed in our study, as the studies of Huber et al. (1981) and Daniel (1983), between serum Ca concentration and ruminal contraction $(r=0.856, p<0.001)$ (Figure $3 a$ ) when serum $\mathrm{Ca}$ concentration ranged from 7.5 to $10.5 \mathrm{mg} / \mathrm{dL}$. This result suggests that inactive ruminal contraction might be due to lower serum Ca concentration, and its weaken contraction soon after parturition could be recovered by improvement of serum $\mathrm{Ca}$ when it was below the normal range by parturition.

Average DM intake during $14 \mathrm{~d}$ before parturition in our study was $1.6 \% \mathrm{BW}$ in both groups which is in agreement with the studies reported by Bertics et al. (1992) and Hayirli et al. (1999), however, DM intake is not a constant value (Hayirli et al., 2002), and the DM intake decreases before parturition and increases following parturition is huge in dairy cows (Vandehaar et al., 1999). Generally, the lowest DM intake was observed at parturition day (Ingvartsen and Andersen, 2000), but in our study, the lowest DM intake was observed at d 1 prior to parturition and, DM intake started to increase on parturition day. This might be due to changes of feeding diets (from TMR formulated by F:C of 89:11 to TMR formulated by $F: C$ of $76: 24)$ and changes of feeding procedures (from TMR and hay restricted feeding to TMR ad-libitum feeding+concentrate supplement) on that parturition day. Following parturition, the cows supplied DFA III in our study tended to have a numerically higher feed intake than the cows not supplied DFA III (Table 3), but there were no statistical differences between the groups $(p>0.05)$. This was due to large variations in DM intake within the groups as in case of serum $\mathrm{Ca}$ concentration. However, positive correlations were observed in our study between serum Ca concentration and
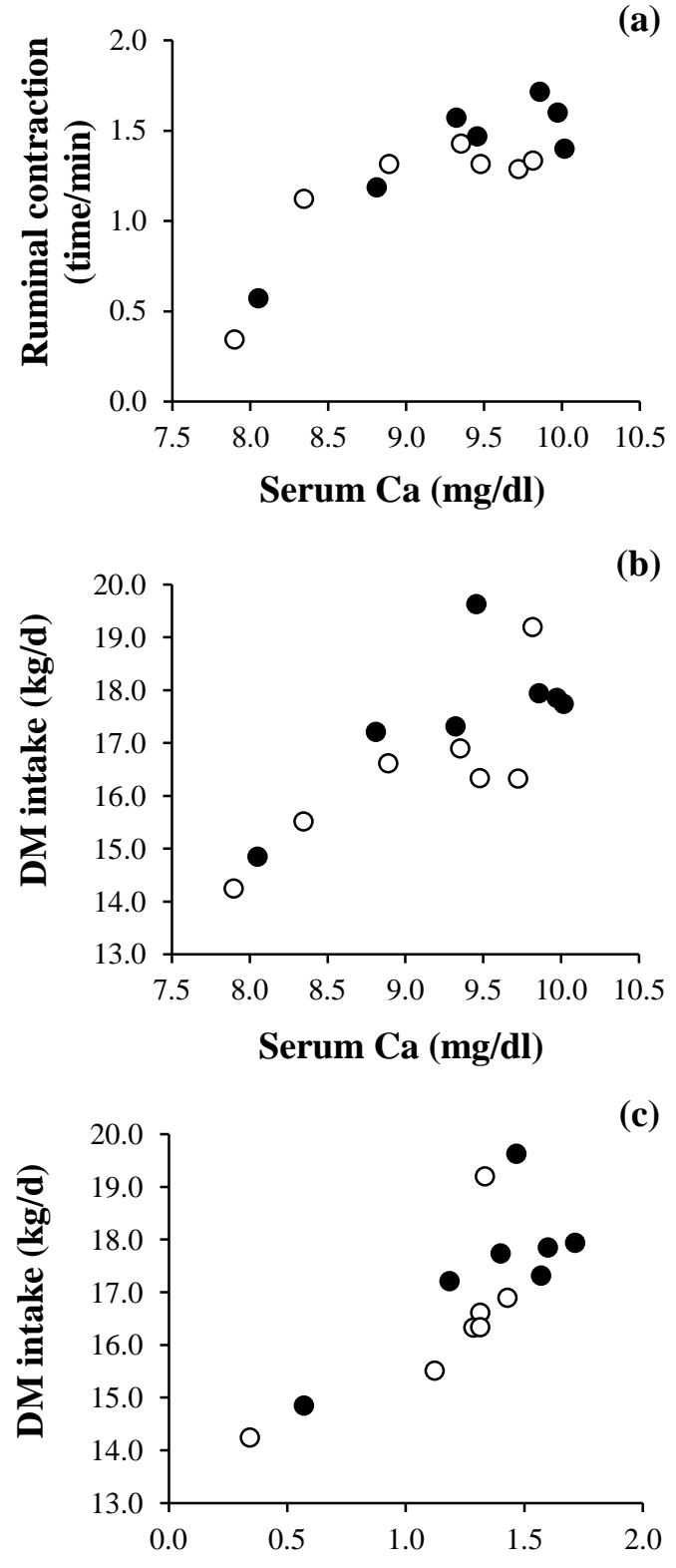

Ruminal contraction (time/min)

Figure 3. Correlations (a) between average serum calcium (Ca) concentration $(\mathrm{mg} / \mathrm{dL})$ and average ruminal contraction (time/min) $(\mathrm{r}=0.856, \mathrm{p}<0.001)$, (b) between average serum $\mathrm{Ca}$ concentration $(\mathrm{mg} / \mathrm{dL})$ and average dry matter $(\mathrm{DM})$ intake $(\mathrm{kg} / \mathrm{d})(\mathrm{r}=0.776$, $\mathrm{p}<0.001$ ), and (c) between average ruminal contraction (time/min) and average DM intake $(\mathrm{kg} / \mathrm{d})(\mathrm{r}=0.773, \mathrm{p}<0.001)$, during first 7 $\mathrm{d}$ following parturition. Symbols: $(\bullet)$ represents to the cows in difructose anhydride (DFA) group that received DFA III supplement, and (O) represents to the cows in CONT group that did not receive any DFA III.

DM intake $(r=0.776, \mathrm{p}<0.001)$ (Figure $3 \mathrm{~b}$ ), and between ruminal contraction and DM intake $(r=0.773, \mathrm{p}<0.001)$ (Figure 3c). These correlations obtained from our study (Figures 3a, b, and c) indicate that serum Ca concentration, ruminal contraction and DM intake are closely related to 
Table 5. Multiple regression analysis for average DM intake during first $7 \mathrm{~d}$ following parturition $\left(\mathrm{kg} / \mathrm{d}, \mathrm{R}^{2}=0.824, \mathrm{p}<0.001\right)$

\begin{tabular}{|c|c|c|c|c|}
\hline Variables, during first $7 \mathrm{~d}$ following parturition & $\mathrm{r}^{1}$ & Partial regression coefficient & p-value ${ }^{2}$ & $\beta^{3}$ \\
\hline Average serum Ca concentration $(\mathrm{mg} / \mathrm{dL})$ & 0.776 & 1.119 & $<0.001$ & 0.526 \\
\hline Average ruminal contraction (time/min) & 0.773 & 0.989 & $<0.001$ & 0.248 \\
\hline Average milk yield $(\mathrm{kg} / \mathrm{d})$ & 0.890 & 0.253 & $<0.001$ & 1.257 \\
\hline Daily body weight change $(\mathrm{kg} / \mathrm{d})$ & 0.493 & 0.015 & 0.037 & 0.159 \\
\hline Intercept & & 18.361 & $<0.001$ & \\
\hline
\end{tabular}

DM, dry matter.

${ }^{1} \mathrm{r}$, single correlation between dependent variable and each explanatory variable.

${ }^{2} \mathrm{p}$-value is for partial regression coefficient of multiple regression analysis.

${ }^{3} \beta$, the standardized partial regression coefficient of multiple regression analysis.

each other, and improvement of feed intake soon after parturition might be reflected by either active ruminal contraction or specific higher concentration of serum $\mathrm{Ca}$ or both. It is certain that serum $\mathrm{Ca}$ concentration is the physiologically active fraction for muscular contraction including the smooth muscle of gastrointestinal tract (Johansson, 1987; Van Breemen and Saida, 1989). Depression of ruminal motility was due to lower level of serum Ca concentration, and it has already been identified for cows by Daniel (1983). Goff (2004) also reported that cow with lower level of serum Ca concentration typically developed inactive digestive tract motility. It means that improvement to an optimal concentration of serum Ca may cause the activation of ruminal contraction. Consequently, an active frequency of ruminal contractions may promote the passage rate of digesta through the gastrointestinal tract, which may reduce the degree of ruminal fill and increase the cows' appetite, resulting in an increase of feed intake (Forbes, 1995). In fact, if the low serum Ca concentration by parturition could not be improved soon after parturition, it might be impossible to increase DM intake following parturition because of weaken ruminal contractions. Overall, findings from these reports indicate that a rapid recovery of serum Ca soon after parturition is practical solution not only to increase the frequency of ruminal contractions but also to improve DM intake in dairy cows.

DM intake is complicated in dairy cows. There are numerous factors restricting DM intake of dairy cows as reported by Grant and Albright (1995), Ingvartsen and Andersen (2000), NRC (2001), and Hayirli et al. (2002). According to the multiple regression equation obtained from our study $\left(\mathrm{R}^{2}=0.824, \mathrm{p}<0.001\right)$ (Table 5), average daily DM intake during first $7 \mathrm{~d}$ following parturition was positively influenced by the average of serum $\mathrm{Ca}$ concentration, ruminal contraction, milk yield and daily BW change during that period. The standardized partial regression coefficient of the equation was the highest for milk yield (1.257), and second highest for serum $\mathrm{Ca}$ concentration (0.526), and third highest for ruminal contraction (0.248). This regression suggests the importance of serum $\mathrm{Ca}$ concentration and ruminal contraction for improving DM intake, and DM intake soon after parturition in dairy cows could be increased by increasing serum $\mathrm{Ca}$ concentration or the frequency of ruminal contraction. Though factors affecting feed intake of dairy cows after parturition are numerous and complex (Grant and Albright, 1995; Ingvartsen and Andersen, 2000; NRC, 2001), serum $\mathrm{Ca}$ concentration and ruminal contractions should be considered as the key factors restricting feed intake.

\section{CONCLUSION}

A clear effect of DFA III on serum Ca concentration was not obtained in our study, and first hypothesis was rejected. More data is required to prove the detail effectiveness of DFA III. On the other hand, second hypothesis was proved in our study. There was a significant positive effect of serum $\mathrm{Ca}$ concentration on DM intake, and serum $\mathrm{Ca}$ concentration should be considered as a factor playing on feed intake of dairy cows soon after parturition.

\section{ACKNOWLEDGMENTS}

Special thanks are due to staff of Field Science Center (Obihiro University, Japan) for the use of their facilities and their generous help in necessaries. We are highly appreciative to Professor Dr. Kida Katsuya's Laboratory (Obihiro University, Japan) for their kindly analysis of the serum components.

\section{REFERENCES}

AOAC. 2003. Official Methods of Analysis. 17th edn. Association of Official Analytical Chemists, Arlington, VA, USA.

Ballard, S. T., J. H. Hunter, and A. E. Taylor. 1995. Regulation of tight junction permeability during nutrient absorption across the intestinal epithelium. Annu. Rev. Nutr. 15:35-55.

Bertics, S. J., R. R. Grummer, C. Cardorniga-Valino, and E. E. Stoddard. 1992. Effect of prepartum dry matter intake on liver triglyceride concentration and early lactation. J. Dairy Sci. 75:1914-1922.

Borsberry, S. and H. Dobson. 1989. Periparturient diseases and their effect on reproductive performance in five dairy herds. 
Vet. Rec. 124:217-219.

Bronner, F. 1992. Current concept of calcium absorption: an overview. J. Nutr. 122:641-643.

Coblentz, W. K., P. C. Hoffman, and N. P. Martin. 2010. Effects of spontaneous heating on forage protein fractions and in situ disappearance kinetics of crude protein for alfalfa-orchard grass hays packaged in large round bales. J. Dairy Sci. 93:1148-1169.

Curtis, C. R., H. N. Erb, C. J. Sniffen, R. D. Smith, P. A. Powers, M. C. Smith, M. E. White, R. B. Hilman, and E. J. Pearson. 1983. Association of parturient hypocalcemia with eight periparturient disorders in Holstein cows. J. Am. Vet. Med. Assoc. 183:559-561.

Daniel, R. C. W. 1983. Motility of the rumen and abomasum during hypocalcemia. Can. J. Comp. Med. 47:276-280.

Drackley, J. K. 1999. Biology of dairy cows during the transition period: the final frontier. J. Dairy Sci. 82:2259-2273.

Drackley, J. K., H. M. Dann, G. N. Douglas, N. A. Janovick, N. B. Litherland, J. P. Underwood, and L. L. Loor. 2005. Physiological and pathological adaptations in dairy cows that may increase susceptibility to periparturient diseases and disorders. Ital. J. Anim. Sci. 4:323-344.

Forbes, J. M. 1995. Voluntary food intake and diet selection in farm animals. CAB International Oxon, UK.

Goff, J. P. 2004. Macromineral disorders of the transition cow. Vet. Clin. North Am. Food Anim. Pract. 20:471-494.

Goff, J. P. and R. L. Horst. 1993. Oral administration of calcium salts for treatment of hypocalcemia in cattle. J. Dairy Sci. 76:101-108.

Goff, J. P. and R. L. Horst. 1997. Physiological changes at parturition and their relationship to metabolic disorders. J. Dairy Sci. 80:1260-1268.

Goff, J. P., T. A. Reinhardt, and R. L. Horst. 1991. Enzymes and factors controlling vitamin D metabolism and action in normal and milk fever cows. J. Dairy Sci. 74:4022-4032.

Grant, R. J. and J. L. Albright. 1995. Feeding behavior and management factors during the transition period in dairy cattle. J. Anim. Sci. 73:2791-2803.

Grummer, R. R., D. G. Mashek, and A. Hayirli. 2004. Dry matter intake and energy balance in the transition period. Vet. Clin. North Am. Food Anim. Pract. 20:447-470.

Hayirli, A., R. R. Grummer, E. Nordheim, P. Crump, D. K. Beede, M. J. VandeHaar, L. H. Kilmer, J. K. Drackley, D. J. Carroll, G. A. Varga, and S. S. Donkin. 1999. Prediction equations for dry matter intake of transition cows fed diets that vary in nutrient composition. J. Dairy Sci. 82:113-113.

Hayirli, A., R. R. Grummer, E. V. Nordheim, and P. M. Crump. 2002. Animal and dietary factors affecting feed intake during the prefresh transition period in Holsteins. J. Dairy Sci. 85:3430-3443.

Herdt, T. H. 1988. Fuel homeostasis in the ruminant. Metabolic diseases of ruminant livestock. Vet. Clin. North Am. Food Anim. Pract. 4:213-231.

Horst, R. L., J. P. Goff, and T. A. Reinhardt. 1990. Advancing age results in reduction of intestinal and bone 1, 25dihydroxyvitamin D receptor. Endocrinology 126:1053-1057.

Horst, R. L., J. P. Goff, T. A. Reinhardt, and D. R. Buxton. 1997. Strategies for preventing milk fever in dairy cattle. J. Dairy Sci. 80:1269-1280.
Huber, T. L., R. C. Wilson, A. J. Stattelman, and D. D. Goetsch. 1981. Effect of hypocalcemia on motility of the ruminant stomach. Am. J. Vet. Res. 42:1488-1490.

Ingvartsen, K. L. and J. B. Andersen. 2000. Integration of metabolism and intake regulation: a review focusing on periparturient animals. J. Dairy Sci. 83:1573-1597.

Johansson, B. 1987. Calcium and regulation of contraction: a short review. J. Cardiovasc. Pharmacol. 10:9-13.

Jonsson, G. and B. Pehrson. 1970. Trials with prophylactic treatment of parturient paresis. Vet. Rec. 87:575-578.

Jonsson, N., P. M. Pepper, R. C. Daniel, M. R. McGowan, and W. J. Fulkerson. 1999. Association between non-parturient postpartum hypocalcaemia and the interval from calving to first ovulation in Holstein-Friesian dairy cows. Anim. Sci. 69:377-383.

Kamiya, Y., M. Kamiya, M. Tanaka, and S. Shioya. 2005. Effects of calcium intake and parity on plasma minerals and bone turnover around parturition. Anim. Sci. J. 76:325-330.

Kikuchi, H., M. Inoue, H. Saito, H. Sakurai, T. Aritsuka, F. Tomita, and A. Yokota. 2009. Industrial production of difructose anhydride III (DFA III) from crude inulin extracted from chicory roots using Arthrobacter sp.H65-7 fructosyltransferase. J. Biosci. Bioeng. 107:262-265.

Kimura, K., T. A. Reinhardt, and J. P. Goff. 2006. Parturition and hypocalcemia blunts calcium signals in immune cells of dairy cattle. J. Dairy Sci. 89:2588-2595.

Kume, S., K. Nonaka, and T. Oshita. 2003. Relationship between parity and mineral status in dairy cows during the periparturient period. Anim. Sci. J. 74:211-215.

Mineo, H., H. Hara, N. Shigematsu, Y. Okuhara, and F. Tomita. 2002. Melibiose, difructose anhydride III and difructose anhydride IV enhance net calcium absorption in rat small and large intestinal epithelium by increasing the passage of tight junctions in vitro. J. Nutr. 132:3394-3399.

Mineo, H., M. Amano, H. Chiji, N. Shigematsu, F. Tomita, and H. Hara. 2004. Indigestible disaccharides open tight junctions and enhance net calcium, magnesium, and zinc absorption in isolated rat small and large intestinal epithelium. Dig. Dis. Sci. 49:122-132.

National Research Council (NRC). 2001. Nutrient Requirements of Dairy Cattle, 7th Ed. National Academy Press. Washington, DC, USA.

Ramberg, C. F., G. P. Mayer, D. S. Kronfeld, J. M. Phang, and M. Berman. 1970. Calcium kinetics in cows during late pregnancy, parturition, and early lactation. Am. J. Physiol. 219:1166-1177.

Romo, G. A., R. O. Kellems, K. Powell, and M. V. Wallentine. 1991. Some blood minerals and hormones in cows fed variable mineral levels and ionic balance. J. Dairy Sci. 74:3068-3077.

Sato, T., M. Hanada, M. Ohtani, T. Nakai, M. Teramura, H. Sadoya, T. Takahashi, and A. Hongo. 2012. Short communication: Effect of difructose anhydride III on serum immunoglobulin $\mathrm{G}$ concentration in newborn calves. J. Dairy Sci. 95:5336-5339.

Sato, T., T. Nakai, H. Sadoya, M. Ohtani, M. Hanada, and M. Okamoto. 2007. Effect of difructose anhydride III on hypocalcemia in dairy cows after calving. Anim. Sci. J. 78:3743. (in Japanese)

Shigematsu, N., Y. Okuhara, T. Shiomi, F. Tomita, and H. Hara. 2004. Effect of difructose anhydride III on calcium absorption 
in human. Biosci. Biotechnol. Biochem. 68:1011-1016.

Suzuki, T., H. Hara, T. Kasai, and F. Tomita. 1998. Effects of difructose anhydride III on calcium absorption in small and large intestines of rats. Biosci. Biotechnol. Biochem. 62:837841.

Van Breemen, C. and K. Saida. 1989. Cellular mechanisms regulating $\left[\mathrm{Ca}^{2+}\right]$ i smooth muscle. Annu. Rev. Physiol. 51:315329.
Van Soest, P. J., J. B. Robertson, and B. A. Lewis. 1991. Methods for dietary fiber, neutral detergent fibre, and non-starch polysaccharides in relation to animal nutrition. J. Dairy Sci. 74:3583-3597.

Vandehaar, M. J., G. Yousif, B. K. Sharma, T. H. Herdt, R. S. Emery, M. S. Allen, and J. S. Liesman. 1999. Effect of energy and protein density of prepartum diets on fat and protein metabolism of dairy cattle in the periparturient period. J. Dairy Sci. 82:1282-1295. 